\title{
STEROID RESISTANT NEPHROTIC SYNDROME-GENETIC CONSIDERATION
}

\author{
Velibor Tasic', Zoran Gucev¹, Momir Polenakovic ${ }^{2}$ \\ ${ }^{1}$ University Children's Hospital, Medical School Skopje, R. Macedonia \\ ${ }^{2}$ Macedonian Academy of Sciences and Arts, Skopje, R. Macedonia
}

Corresponding Author: Prof. Velibor Tasic, MD, PhD, University Children's Hospital, 17 Vodnjanska, 1000 Skopje, R. Macedonia; Tel. + 389757891 05; E-mail: vtasic2003@gmail.com

\begin{abstract}
Nephrotic syndrome is defined as the association of massive proteinuria, hypoalbuminaemia, edema, and hyperlipidemia. It is separated to steroid-sensitive or steroid-resistant (SRNS) forms in respect to the response to intensive steroid therapy. SRNS usually progresses to end-stage renal failure. According to the North American Pediatric Renal Trials and Collaborative Studies SRNS constitutes the second most frequent cause of ESRD in the first two decades of life. Unfortunately, there is no curative treatment for majority of patients. Majority of the SRNS patients have the histologic picture of focal segmental glomerulosclerosis. Interestingly, the risk of recurrence in the kidney graft in patients with hereditary SRNS is lower than in those who do not have genetic background. The etiology and pathogenesis of SRSN has remained enigma for decades. The discovery of 39 dominant or recessive SRNS genes enabled better understanding of the function of the glomerular podocytes and slit membrane. Hildebrandt's group has shown that $85 \%$ of the SRNS cases with onset by 3 months of age and $66 \%$ with onset by 1 year of age can be explained by recessive mutations in one of four genes only (NPHS1, NPHS2, LAMB2, or WT1). The same group used modern diagnostic techniques such as the next generation sequencing and tested a large international cohort of SRNS patients $(\mathrm{n}=1783$ families $)$. The diagnostic panel included 21 genes with a recessive mode of inheritance and 6 genes with a dominant mode of inheritance. Single-gene cause was detected in $29.5 \%$ (526 of 1783) of the families with SRNS that manifested before 25 years of age. The identification of causative single-gene mutations may have important therapeutic consequences in some cases. This is very important for patients who carry mutations in a gene of coenzyme Q10 biosynthesis (COQ2, COQ6, ADCK4, or PDSS2). In these patients the treatment with coenzyme Q10 may be indicated. Also, patients with recessive mutations in PLCE1 may respond fully to the treatment with steroids or cyclosporine A. The patients with $C U B N$ may benefit the treatment with vitamin B12. The detection of causative mutations may also be very important for familial genetic counseling and for prenatal diagnosis.
\end{abstract}

Key words: nephrotic syndrome, steroid-resistant, genetics, children

Nephrotic syndrome is a rare disease characterized clinically with the presence of edema and biochemically with massive proteinuria (> $40 \mathrm{mg} / \mathrm{m}^{2} / \mathrm{h}$, or $>50 \mathrm{mg} / \mathrm{kg} / \mathrm{d}$ ), hypoalbuminaemia $(<25 \mathrm{~g} / \mathrm{l})$ and hyperlipidemia. In respect to the response to intensive steroid therapy it is classified as steroid-sensitive or steroid-resistant nephrotic syndrome (SRNS). SRNS usually progresses to end-stage renal disease (ESRD).
The prevalence of steroid resistant form is $15 \%$ in children while in adults it is higher $-40 \%$. According to the North American Pediatric Renal Trials and Collaborative Studies SRNS constitutes the second most frequent cause of the ESRD in the first two decades of life [1]. Majority of the SRNS patients have the histologic picture of focal segmental glomerulosclerosis, but also minimal change disease and me- 
sangioproliferative glomerulonephritis may be seen. Recurrence of the disease in the kidney graft is significantly lower in patients who have genetic background than in those who do not have it. The treatment of SRNS is a challenging task for the nephrologists due to its poor response to immnosupressive drugs. High dose steroids, cyclopsphamide, calcineurin inhibitors (cyclosporine and tacrolimus), mophetil mycophenolate and rituximab have been used with variable success rates in children and adults [2].

\section{Pathogenesis}

\section{Circulating factor}

It has been speculated that a circulating permeability factor is responsible for the pathogenesis of the disease due to the fact that many patients with FSGS develop proteinuria and recurrence of the disease shortly after transplantation. Cardiotrophin-like cytokine 1 (CLC-1) and anti-CD40 antibody have been incriminated as potential circulating permeability factors [3]. Recently Reiser's group suggested that soluble urokinase-type plasminogen activator receptor (suPAR) might be involved in the pathogenesis of primary FSGS and might be used as a useful diagnostic biomarker [4]. There is a strong evidence that serum suPAR levels are negatively associated with the renal function and can scarcely differentiate FSGS from the other glomerular/renal diseases. The researchers could not prove in vivo studies that suPAR upregulation could induce proteinuria or podocyte injury. One may hypothetise that a different form of suPAR, which cannot be measured by current enzyme-linked immunosorbent assay, might be the potential permeability factor and biomarker, but a lot of work has to be done to prove it.

\section{Structure of the glomerular barrier}

In the past, the attention of the researches was addressed to the masangial cell as the crucial target in the pathogenesis of SRNS. With the discovery of the structural podocyte genes this attention was redirected to the podocyte which became the principal cell and therefore the resulting pathology was termed podocytopathy. It was demonstrated in the rodent model that podocytes are essential for normal glome- rular function and their structural and functional damage is sufficient to cause FSGS.

The podocyte is very similar to the neuronal cell since it branches off cellular processes to cover the outside of the glomerular capillary, with primary, secondary and tertiary cellular processes, the latter called 'foot processes'. They interdigitate with foot processes from neighboring podocytes and create the glomerular slit membrane, which is very important for the filtering process and retention of protein in the blood stream. The structural and functional changes in the slit membrane result in the lost of its integrity, proteinuria and nephrotic syndrome. So far, 39 dominant and recessive genes have been discovered in patients with SRNS [5]. The identification of these genes was very important for our understanding of the physiology of glomerular filtration barrier and of the pathogenic mechanisms which operate in SRNS.

\section{Identification of the first structural genes} Nephrin (NPHS1)

Ahvenainen et al in 1956 described a series of 8 infants from Finish ancestry who presented with severe congenital nephrotic syndrome (CNS) and died within the first year of life [6]. In 1998 Kestilä and co-workers identified the gene responsible for the congenital nephrotic syndrome of Finnish type and entitled it nephrin (NPHS1) [7]. They characterized the nephrin as a transmembrane adhesion protein which belongs to the immunoglobulin family and which contains 1,241 amino acids. Nephrin takes part in cell signaling and is important in connecting the slit diaphragm to the actin cytoskeleton of the podocyte foot process. So far more than 200 mutations in NPHS1 have been reported (www.biobase-international.com), which usually leads to an early and severe clinical form of CNS. Two founder mutations are typical for the Finnish patients: Fin-major (nt121(del2)) and Fin-minor (R1109X). The prevalence of the disease is 1/8000 in Finland. These babies are born with low birth weight ranging from 1500-3500 grams but the placenta is large (> $25 \%$ of the birth weight). The extrarenal abnormalities are usually absent. Proteinuria begins in utero and is detected in the first neonatal urine. As already mentioned, 
these patients in the past died, but nowadays with the improvement of the nephrological care, they survive and have much better outcome [8]. This is achieved with daily albumin infusions, antiproteinuric therapy with indomethacine and captopril and in some cases with unilateral nephrectomy. In the most severe cases the bilateral nephrectomy is performed, the babies are treated with peritoneal dialysis and aggressive nutritional support until they achieve the body weight of $10 \mathrm{~kg}$ to undergo a kidney transplantation.

\section{Podocin (NPHS2)}

In 2000, Antignac's group from Paris described another gene, NPHS2, which encodes another structural podocyte protein named podocin [9]. Mutations in NPHS2 can manifest early as an infantile nephrotic syndrome, but may also manifest later in life. Podocin interacts with nephrin and serves as a scaffolding function for the slit diaphragm.

Mutations in podocin (NPHS2) are the most common cause of childhood onset autosomal recessive steroid-resistant nephrotic syndrome (SRNS). The patients are resistant to the immunosuppressive therapy and rapidy progress to end-stage renal disease. The podocin variant R229Q combined with another pathogenic mutation has been associated with a mild phenotype with disease onset often in adulthood.

Jain et al reported a non-consanguineous family with three generations of individuals who were either compound heterozygotes for mutations in NPHS2 (R138Q and Q215X) or who have inherited a mutation and a non-neutral polymorphism (R229Q) [10]. The father and the daughter had a childhood onset SRNS. Although the initial assessment pointed to the dominant inheritance of SRNS in this family a careful clinical and genetic testing of the relatives clarified the complex pattern of inheritance. It is of note that variant R229Q in combination with the pathogenic NPHS2 mutation in trans position may cause SRNS of adult onset. Further, what makes the situation complicated, the grandfather in the family reported by Jain et al carried non neutral polymorphism R229Q and known pathogenic mutation R138Q but was healthy at the age of 69 . This may be further explained by the recent report by Tory et al. who showed that R229Q is only pathogenic when in trans association with specific NPHS2 mutations [11]. Mutations in exons 1-6 of the NPHS2 gene (which includes $\mathrm{R} 138 \mathrm{Q})$ are unlikely to be pathogenic in association with $\mathrm{R} 229 \mathrm{Q}$, as there was a healthy grandfather.

\section{WT1 gene}

WT1 mutations can clinically present with three different phenotypes associated with steroid resistant nephrotic syndrome: (i) Denys-Drash syndrome (DDS) (ii) Frasier syndrome (FS) and (iii) isolated nephrotic syndrome. DDS patients besides early nephrotic syndrome have ambiguous genitals and tend to develop Wilms tumor. The typical renal histology picture is of diffuse mesangial sclerosis. Patients with Frasier syndrome present with SRNS later than DDS patients and have male pseudohermaphroditism. Focal segmental glomerulosclerosis is the dominant histological picture. Patients with "isolated nephrotic syndrome" do not tend to develop Wilms tumor and there are no major urogenital abnormalities. In majority of the patients (> 95\%) with nephrotic syndrome and WT1 mutations the location of the mutations is in exon 8 or 9 of the WT1 gene. Typically Frasier patients have mutations in the donor splice-site of intron 9. The diagnosis of the WT1 mutation in patients with SRNS is of utmost clinical importance in respect of the further careful clinical surveillance for prevention of the development of Wilms tumor or gonadoblastoma.

\section{Genetics of SRNS in the next generation sequencing era}

In the past, the diagnosis of the monogenic causes of SRNS was performed using the Sanger sequencing, which is a laborious and costly technique. With the advance in the genetic technologies, it is now possible to test $>30$ genes simultaneously by using high throughput PCR amplification and sequencing approaches. Gene panels include known genes and enable faster and cheaper diagnosis compared with the classic Sanger sequencing [12]. The whole exome sequencing enables sequencing of the whole human exome (300.000 exomes) and 
detection of new SRNS genes, particularly in patients who had negative panel results. Owing to whole exome sequencing many new SRNS genes have been detected. Very interesting and valuable information was gathered from two big international studies (Hildebrand's group and PODONET study).

\section{Hildebrandt's study}

The Hildebrandt's group used modern diagnostic techniques such as next generation sequencing and tested a large international cohort of SRNS patients ( $\mathrm{n}=1783$ families) [13]. The diagnostic panel included 21 genes with a recessive mode of inheritance (NPHS2, NPHS1, PLCE1, LAMB2, SMARCAL1, COQ6, ITGA3, MYOIE, COQ2, CUBN, ADCK4, DGKE, PDSS2, ARHGDIA, CD2AP, CFH, ITGB4, NEIL1, PTPRO/GLEPP1, SCARB2, and $M E F V$ ) and 6 genes with a dominant mode of inheritance (WT1, INF2, TRPC6, ARHGAP24, $A C T N 4$ and $L M X 1 B$ ). Causative mutations were detected in 21 of 27 tested genes. The genetic diagnosis was established in 526 of 183 families $(29.5 \%)$. This study showed that four genes were major SRNS genes: NPHS2 (9.93\%), NPHS1 (7.34\%), WT1 (4.77\%) and PLCE1 $(2.17 \%)$. The highest rate of mutation detection of $69.4 \%$ was in the youngest group of patients (0-3 months) and this percentage decreased with the older age. The second important finding from this study was that mutations in recessive genes were more common in children while dominant genes were prevalent in adults. Dominant genes are less penetrant and cause SRNS in adults with phenotypic variability. The most prevalent dominant genes are INF2, TRPC6 and ACTN4.

The identification of causative singlegene mutations may have important therapeutic consequences in some cases. This is very important for patients who carry mutations in a gene of coenzyme Q10 biosynthesis (COQ2, COQ6, $A D C K 4$, or PDSS2). In these patients the treatment with coenzyme Q10 may be indicated. An illustrative example is presented by this group; a 5-yearold girl presented with SRNS and a causative homozygous mutation was detected in the COQ6 gene [14]. She had previously responded partially to the treatment with cyclosporine A. The treatment with coen- zyme Q10 was commenced during the remission and her proteinuria was minimal. Following the inadvertent interruption of coenzyme Q10 administration, the proteinuria rose into the nephrotic range, but after the reinstitution of therapy, the proteinuria normalized.

Also, patients with recessive mutations in PLCE1 may respond fully to the treatment with steroids or cyclosporine A $[15,16]$. The patients with $C U B N$ may benefit the treatment with vitamin B12 [17]. Individuals with ARHGDIA may theoretically be responsive to the eplerenone treatment.

\section{Podonet Study}

The PodoNet Consortium has established an international registry for studying congenital nephrotic syndrome and childhood-onset steroid-resistant nephrotic syndrome. Since 2009 more than 1655 patients' data have been collected and mutation screening has been performed in 1184 patients [18]. In majority of the patients $(64 \%)$ the SRNS manifested in the first five years of life and the congenital form accounted for $6 \%$ of all patients. The most common histological picture was FSGS. Genetic disease was identified in $23.6 \%$ patients. Causative mutations were detected in 14 SRNS genes and the most common mutated genes were NPHS2, WT1 and NPHS1. This study showed similar trend as Hildebrand's study - the percentage of patients with genetic form decreased with the increased age; this percentage was $66 \%$ in patients with congenital nephrotic form, while in school children and adolescents it decreased to $15-16 \%$. This study showed presence of extrarenal abnormalities in $17.3 \%$ patients. The most common abnormalities were: short stature $5.1 \%$, mental retardation $3.9 \%$, anomalies in the central nervous system 2.5 , facial dysmorphysm $2.2 \%$, cardiac structural disorders $2.2 \%$, urogenital anomalies $2.0 \%$, visual impairment $1.9 \%$, hearing disorder $1.5 \%$ etc. Concerning the treatment outcome the best effects were observed with the administration of calcineurin inhibitors and rituximab with $40 \%-45 \%$ of the patients achieving complete remission. This study revealed two additional important conclusions (i) that genetic diagnosis (not hitology) was predictive for immunosuppressive treatment response and (ii) that post-transplant 
disease recurrence was significantly lower in patients with genetic diagnosis $(4.5 \%$ versus $25.8 \%)$.

\section{Other studies}

In a small Brazilian study 27 steroid-resistant nephrotic syndrome patients wete tested for mutations in NPHS1, NPHS2 and WT1 gene [19]. Only mutations in NPHS2 were detected confirming the hereditary character of the kidney disease in only $14.8 \%$ of patients.

A molecular genetic analysis of childhood nephrotic syndrome was performed in a cohort of 49 Saudi Arabian families (62 cases) [20]. The following genes were screened: NPHS1, NPHS2, LAMB2, PLCE1, CD2AP, MYO1E, $W T 1, P T P R O$ and Nei endonuclease VIII-like 1 (NEIL1). Causative mutations were identified in 25 families $(51 \%)$. The most common mutated genes were NPHS2 (22\%), NPHS1 (12\%) and PLCE1 (8\%).

Giglio et al performed next-generation sequencing analysis of 19 target genes in a cohort of 31 children affected by sporadic steroid-resistant nephrotic syndrome and 38 patients who had steroid-sensitive clinical phenotype [21]. The genetic background was established in $32.3 \%$ of the children with steroidresistant disease but zero of 38 children with steroid-sensitive disease. The response to immunosuppressive treatment in children with genetic and non-genetic steroid resistant nephrotic syndrome was 0 and $57.9 \%$ respectively.

Hildebrandt's group reported that mutations in EMP2 can cause childhood-onset nephrotic syndrome. Interestingly mutations in this gene were detected in 4 individuals from three families who showed steroid resistant or steroid sensitive phenotype [22].

Bińczak-Kuleta et al analyzed NPHS1, NPHS2, WT1 and LAMB2 genes in 33 Polish children with SRNS due to the focal segmental glomerulosclerosis (FSGS), manifesting before the age of 13 years old [23]. No pathogenic mutations were found in NPHS1 or LAMB2 genes. Causative mutations of NPHS2 and WT1 were detected in 7 of 33 patients $(21 \%)$, including those with nephrotic syndrome manifesting before one year old: five of seven patients.

Jaffer et al studied a cohort of 484 subjects from the southern Indian population for the presence of four missense mutations G92C,
P118L, R138Q and D160G within the NPHS2 gene [24]. These mutations were found in $18.5 \%$ of steroid-resistant patients in their study group, but not in controls and steroid sensitive patients.

In a report from Turkey 295 children with SRNS were included in mutational analysis of the NPHS2 gene [25]. Forty-one patients $(13.8 \%)$ had familial nephrotic syndrome. The mutation detection rate was $24.7 \%$ for all patients and the most common mutated exon was exon 5 ( 52 allele). The patients with mutations in exon 4 had increased risk for progression to end-stage renal disease (ESRD). The mean time of progression to renal failure and ESRD in patients with mutations $(1.8 \pm 2.5$ years) was significantly shorter than in patients without mutations $(3.7 \pm 4.0$ years $)$.

\section{Future perspectives and clinical implications}

There is evidence that angiotensin-converting enzyme (ACE) inhibitors and angiotensin receptor blockers (ARB) may have beneficial effect in patients with SRNS, but the mechanism of the action was obscure. Recently a calcium mediated pathway has been identified that connects the angiotensin type 1 receptor (AT1R) to podocyte cytoskeletal dynamics, which is important for a functioning glomerular filtration barrier [26]. The discovery of the two $\mathrm{Ca}^{2+}$ permeant channels TRPC5 and TRPC6 as mediators of this pathway not only bolstered the importance of podocyte cytoskeleton dynamics but also revealed promising drug targets for the treatment-resistant nephrotic syndrome.

From a clinical point of view the detection of causative mutations is important because:

- There is no benefit from immunosupressants;

- No recurrence after renal transplantation;

- No need for renal biopsy;

- Living related transplant donors may be acceptable particularly in those with recessive mutations;

- Familial genetic counseling;

- Prenatal diagnosis;

- Carriers of WT1 mutations should be monitored for Wilm's tumor and gonadoblastoma.

Therefore, pediatric and adult nephrologists should learn about the genetics of SRNS. Detection of new genes and pathophysiology 
events which are important for a provision of a normal function and integrity of the glomerular barrier will enable appropriate pharmacological treatment $[27,28,29,30]$. The achievement of SRNS genetics is an example of personalized medicine where modern research innovations are translated into the clinical practice.

The authors declare no conflict of interests.

\section{REFERENCES}

1. Smith JM, Stablein DM, Munoz R, et al. Contributions of the transplant registry: the 2006 Annual Report of the North American Pediatric Renal Trials and Collaborative Studies (NAPRTCS). Pediatr Transplant 2007; 11: 366373.

2. Lombel RM, Hodson EM, Gipson DS; Kidney Disease: Improving Global Outcomes. Treatment of steroid-resistant nephrotic syndrome in children: new guidelines from KDIGO. Pediatr Nephrol. 2013; 28: 409-14.

3. Wada T, Nangaku M. A circulating permeability factor in focal segmental glomerulosclerosis: the hunt continues. Clin Kidney J. 2015; 8: 708715.

4. Wei C, El Hindi S, Li J, Fornoni A, Goes N, Sageshima J, Maiguel D, et al. Circulating urokinase receptor as a cause of focal segmental glomerulosclerosis. Nat Med. 2011; 17: 952-60.

5. Lovric S, Ashraf S, Tan W, Hildebrandt F. Genetic testing in steroid-resistant nephrotic syndrome: when and how? Nephrol Dial Transplant. 2015 Oct 27. pii: gfv355. [Epub ahead of print]

6. Ahvenainen EK, Hallman N, Hjelt L. Nephrotic syndrome in newborn and young infants. Ann Paediatr Fenn. 1956; 2: 227-241.

7. Kestilä M, Lenkkeri U, Männikkö M, Lamerdin J, McCready P, Putaala H, Ruotsalainen V, et al. Positionally cloned gene for a novel glomerular protein-nephrin is mutated in congenital nephrotic syndrome. Mol Cell. 1998; 1: 575-82.

8. Jalanko H. Congenital nephrotic syndrome. Pediatr Nephrol. 2009; 24: 2121-8.

9. Boute N, Gribouval O, Roselli S, Benessy F, Lee H, Fuchshuber A, Dahan K, et al. NPHS2, encoding the glomerular podocin, is mutated in autosomal recessive steroid-resistant nephrotic syndrome. Nat Genet. 2000; 24: 349-354.

10. Jain V, Feehally J, Jones G, Robertson L, Nair D, Vasudevan P. Steroid-resistant nephrotic syndrome with mutations in NPHS2 (podocin): report from a three-generation family. Clin Kidney J. 2014; 7: 303-5.

11. Tory K, Menyhárd DK, Woerner S, Nevo F, Gribouval O, Kerti A, Stráner P, et al. Mutationdependent recessive inheritance of NPHS2-associated steroid-resistant nephrotic syndrome. Nat Genet. 2014; 46: 299-304.

12. Lovric S, Fang H, Vega-Warner V, Sadowski CE, Gee HY, Halbritter J, Ashraf S, et al. Nephrotic Syndrome Study Group. Rapid detection of monogenic causes of childhood-onset steroidresistant nephrotic syndrome. Clin J Am Soc Nephrol. 2014; 9: 1109-16.

13. Sadowski CE, Lovric S, Ashraf S, Pabst WL, Gee HY, Kohl S, Engelmann S, et al. SRNS Study Group, Hildebrandt F. A single-gene cause in $29.5 \%$ of cases of steroid-resistant nephrotic syndrome. J Am Soc Nephrol. 2015; 26: 1279-89.

14. Heeringa SF, Chernin G, Chaki M, Zhou W, Sloan AJ, Ji Z, Xie LX, et al. COQ6 mutations in human patients produce nephrotic syndrome with sensorineural deafness. J Clin Invest. 2011; 121: 2013-24.

15. Hinkes B, Wiggins RC, Gbadegesin R, Vlangos $\mathrm{CN}$, Seelow D, Nürnberg G, Garg P, et al. Positional cloning uncovers mutations in PLCE1 responsible for a nephrotic syndrome variant that may be reversible. Nat Genet. 2006; 38: 1397-405.

16. Lin T, Li J, Wang F, Cao L, Wu J, Tu J, Ji L, et al. A Chinese girl with novel PLCE1 mutations and proliferation of the mesangium responded to tacrolimus therapy. Nephrology (Carlton). 2014; 19: 173.

17. Ovunc B, Otto EA, Vega-Warner V, Saisawat P, Ashraf S, Ramaswami $G$, et al. Exome sequencing reveals cubilin mutation as a singlegene cause of proteinuria. J Am Soc Nephrol. 2011; 22: 1815-20.

18. Trautmann A, Bodria M, Ozaltin F, Gheisari A, Melk A, Azocar M, Anarat A, et al. PodoNet Consortium. Spectrum of steroid-resistant and congenital nephrotic syndrome in children: the PodoNet registry cohort. Clin $\mathrm{J}$ Am Soc $\mathrm{Ne}$ phrol. 2015; 10: 592-600.

19. Guaragna MS, Lutaif AC, Piveta CS, Souza ML, de Souza SR, Henriques TB, MacielGuerra AT, et al. NPHS2 mutations account for only $15 \%$ of nephrotic syndrome cases. BMC Med Genet. 2015; 16: 88.

20. Al-Hamed MH, Al-Sabban E, Al-Mojalli H, AlHarbi N, Faqeih E, Al Shaya H, Alhasan K, et al. Meyer BF.A molecular genetic analysis of childhood nephrotic syndrome in a cohort of Saudi Arabian families. J Hum Genet. 2013; 58: 480-9. 
21. Giglio S, Provenzano A, Mazzinghi B, Becherucci F, Giunti L, Sansavini G, Ravaglia F, et al. Heterogeneous genetic alterations in sporadic nephrotic syndrome associate with resistance to immunosuppression. J Am Soc Nephrol. 2015; 26: 230-6.

22. Gee HY, Ashraf S, Wan X, Vega-Warner V, Esteve-Rudd J, Lovric S, Fang H, et al. Mutations in EMP2 cause childhood-onset nephrotic syndrome. Am J Hum Genet. 2014; 94: 884-90.

23. Bińczak-Kuleta A, Rubik J, Litwin M, Ryder $\mathrm{M}$, Lewandowska K, Taryma-Leśniak $\mathrm{O}$, Clark JS, et al. Retrospective mutational analysis of NPHS1, NPHS2, WT1 and LAMB2 in children with steroid-resistant focal segmental glomerulosclerosis - a single-centre experience. Bosn J Basic Med Sci. 2014; 14: 89-93.

24. Jaffer A, Unnisa W, Raju DS, Jahan P. NPHS2 mutation analysis and primary nephrotic syndrome in southern Indians. Nephrology (Carlton). 2014; 19: 398-403.

25. Berdeli A, Mir S, Yavascan O, Serdaroglu E, Bak M, Aksu N, Oner A, et al. NPHS2 (podicin) mutations in Turkish children with idiopathic nephrotic syndrome. Pediatr Nephrol. 2007; 22: 2031-40.

26. Wieder N, Greka A. Calcium, TRPC channels, and regulation of the actin cytoskeleton in podocytes: towards a future of targeted therapies. Pediatr Nephrol. 2015 Oct 21. [Epub ahead of print]

27. Gee HY, Zhang F, Ashraf S, Kohl S, Sadowski CE, Vega-Warner V, Zhou W, et al. KANK deficiency leads to podocyte dysfunction and nephrotic syndrome. J Clin Invest. 2015; 125: 2375-84.

28. Ebarasi L, Ashraf S, Bierzynska A, Gee HY, McCarthy HJ, Lovric S, Sadowski CE, et al. Defects of CRB2 cause steroid-resistant nephrotic syndrome. Am J Hum Genet. 2015; 96: 153-61.

29. Korkmaz E, Lipska-Ziętkiewicz BS, Boyer O, Gribouval O, Fourrage C, Tabatabaei M, Schnaidt $\mathrm{S}$, et al. PodoNet Consortium. ADCK4Associated Glomerulopathy Causes Adolescence-Onset FSGS. J Am Soc Nephrol. 2015 May 12. pii: ASN.2014121240. [Epub ahead of print]

30. Miyake N, Tsukaguchi H, Koshimizu E, Shono A, Matsunaga S, Shiina M, Mimura Y, et al. Biallelic Mutations in Nuclear Pore Complex Subunit NUP107 Cause Early-Childhood-Onset Steroid-Resistant Nephrotic Syndrome. Am J Hum Genet. 2015; 97: 555-66.
Резиме

\section{СТЕРОИД РЕЗИСТЕНТЕН НЕФРОТСКИ СИНДРОМ - ГЕНЕТСКО РАЗГЛЕДУВАЫЕ}

\author{
Велибор Тасиќ ${ }^{1}$ Зоран Гучев ${ }^{1}$, \\ Момир Поленаковиќ ${ }^{2}$
}

1 Универзитетска клиника за детски болести, Медицински факултет, Скопје, Р. Македонија

${ }^{2}$ Македонска академија на науките и уметностите, Скопје, Р. Македонија

Нефротски синдром се дефинира како асоцијација на масивна протеинурија, хипоалбуминемија, едеми и хиперлипидемија. Се разликува стероид сензитивна и стероид резистентна форма (СРНС) во однос на одговор на интензивна стероидна терапија. СРНС обично прогредира во терминална уремија. Според NorthAmerican Pediatric RenalTrials and Collaborative Studies, CРНС претставува втора најчеста причина на терминална уремија во првите две декади од животот. За жал, за повеќето пациенти не постои третман на излекување. Поголем број СРНС-пациенти имаат хистолошка слика на фокална сегментна гломерулосклероза. Интересно, ризикот од релапс на болеста во бубрежниот трансплантат кај пациенти со генетска форма е помал отколку кај оние што немаат генетска основа. Етиологијата и патогенезата на СРНC беше енигма со децении. Откритието на 39 доминантни и рецесивни СРНС-гени овозможи подобро познавање на функцијата на гломеруларните подоцити и slit membrane. Групата на Hildebrandt покажа дека 85\% на СРНС-случаи со почеток до три месеци возраст и $66 \%$ со почеток до една година можат да се објаснат со мутации во еден од четирите гена (NPHS1, NPHS2, LAMB2, или WT1). Истата група ги користела модерните дијагностички техники како што e next generation sequencing и тестирала голема интернационална кохорта на СРНС пациенти (н = 1783 фамилии). Дијагностичкиот панел вклучувал 21 рецесивен и 6 доминантни гени. Моногенска причина на СРНС била детектирана кај 29.5\% (526 од 1.783) на фамилии кај кои СРНС се манифестирал пред 25 година од животот. Идентификација на моногенските мутации може да има значајни терапевтски импликации во одредени случаи. Ова е важно за пациенти кои носат мутации во гените на коензим Q10 биосинтезата (COQ2, COQ6, ADCK4, or $P D S S 2)$. Кај овие пациенти третман со коензим Q10 може да биде индициран. Исто така, па- 
циенти со рецесивни мутации во PLCE1 можат комплетно да одговорат на третман со стероиди и циклоспорин А. Пациенти со $C U B N$ мутации можат да имаат корист од третман со витамин Б12. Детекција на причинските мутации е исто многу важна за фамилијарно генетско советување, како и за пренатална дијагноза.

Клучни зборови: нефротски синдром, стероидрезистентен, генетика, деца 